analiza filologiczna nie prowadzi do właściwego rozumienia świętości jest zbyt apodyktyczne i jednostronne. Myślę raczej, że badanie znaczenia terminologii nie wystarczyłoby do zrozumienia świętości, a nie, że w jakiś sposób wykrzywiałoby je, jak można wywnioskować z niektórych sformułowań Autora. Ks. A. Baron zresztą odwołuje się do opracowań terminologii związanej ze świętością i omawia najważniejsze terminy tam, gdzie konieczność tego wymaga.

Monografia ks. A. Barona jest przykładem rzetelnego przekrojowego studium, możliwego do napisania przez badacza dysponującego rozległą wiedzą filozoficzno-teologiczną. Poświadcza w pełni kompetencje Autora do napisania kolejnych tomów dzieła, których środowisko polskich patrologów będzie na pewno oczekiwać z niecierpliwością.

ks. Mariusz Szram - Lublin, KUL

Waldemar CERAN, Artisans et commerçants à Antioche et leur rang social (seconde moitié du $I V^{E}$ siècle de notre ère), traduction de la langue polonaise par Elżbieta Kolańska, édition revue, corrigée et mise à jour par Pawel Filipczak, Byzantina Lodziensia 18, Lódź 2013, Wydawnictwo Uniwersytetu Lódzkiego, ss. XL + 236.

$Z$ wielkim uznaniem i radością należy powitać inicjatywę środowiska łódzkich bizantynistów, którzy oddając hołd wybitnemu uczonemu, znawcy antyku i historii Bizancjum, śp. Profesorowi Waldemarowi Ceranowi, postanowili - poprzez przekład na język francuski - udostępnić szerszemu gronu czytelników, zwłaszcza posługujących się językiem francuskim, jedną z najważniejszych jego prac naukowych dotyczącą historii społecznej późnoantycznej Antiochii.

Omawiana praca została oparta na ogromnej bazie źródłowej obejmującej przede wszystkim dzieła Jana Chryzostoma i Libaniusza, z których tylko niewielkie fragmenty zostały dotychczas przełożone na język polski. Struktura monografii, złożona z czterech rozdziałów, logicznie i konsekwentnie porządkuje całokształt bogatego materiału źródłowego, według założeń zawartych w temacie pracy. W rozdziale pierwszym (który posiada charakter wprowadzający) pt. „La situation d'Antioche et sa importance en Orient" (s. 21-64), Autor przedstawił $\mathrm{w}$ obszernym zarysie kontekst badanej problematyki, uwzględniając zarówno uwarunkowania geograficzne, jak i gospodarczo-kulturowe oraz polityczne starożytnej Antiochii. W rozdziale drugim pt. „Les artisans” (s. 65-135), Autor odwołując się do nazewnictwa przyjętego w języku greckim, wyczerpująco omówił poszczególne grupy zawodowe, zwracając uwagę na ich zróżnicowanie oraz rozwarstwienie ekonomiczno-społeczne. W rozdziale trzecim pt. „Les commerçants" (s. 137-163), ukazał hierarchicznie zróżnicowaną grupę ludzi zajmujących się handlem we wszystkich (zarówno mikro, jak i makro) jego wymiarach. W rozdziale czwartym pt. „Le rang social des artisans et des commerçants" (s. 165-189), zwrócił uwagę na to, że ludzie wymienionych zawodów 
zajmowali niski stopień w ogólnej gradacji społecznej. W podsumowaniu doszedł do wniosku, iż „le critère principal déterminant la place de l'homme dans la société d'alors était son état de fortune" (s. 189).

Eksponując walory omawianej pracy należy zwrócić uwagę na bardzo staranne, wręcz perfekcyjne wykorzystanie bazy źródłowej, w tym szczególnie pism Jana Chryzostoma i Libaniusza. Wszystkie swoje opinie i wywody Autor starannie dokumentuje odwołując się ustawicznie do greckiego oryginału źródłowego. Świadectwem tego są wprowadzone do pracy liczne terminy, a nawet całe zwroty w języku greckim. Podobnie perfekcyjnie została wykorzystana przeogromna literatura przedmiotu. Autor nie poprzestaje na przedstawieniu stanu badań we wstępie pracy („Introduction”, s. 1-20), lecz każdorazowo, przy podejmowaniu kolejnych zagadnień, omawia istniejące opracowania, ustosunkowując się do nich krytycznie. Z poglądami niektórych wybitnych badaczy Autor z powodzeniem polemizuje, eksponując własne opinie, które są owocem dociekliwych i żmudnych analiz tekstów źródłowych. Dzięki tej akrybii Autor krytycznie odnosi się do opinii takich badaczy jak G.L. Kurbatov (np. s. 96, 121-122 i 130-131) czy E. Frances (np. s. 132). W zakresie formułowania opinii i wniosków wykazuje dojrzałość badawczą, unikając nadinterpretacji i sformułowań zbyt radykalnych (np. s. 54-55 i 102-103).

Niewątpliwą zaletą omawianej pracy jest jej niezwykle dostępna forma podawcza oraz płynna narracja. W sposób jasny, prosty i komunikatywny, a zarazem kompetentny i rzeczowy, Autor relacjonuje omawiane treści, rezygnując z tak ulubionej przez wielu współczesnych badaczy zawiłej terminologii, naszpikowanej neologizmami oraz terminami obcojęzycznymi. Umiejętnie wplata do swego wykładu teksty źródłowe, dzięki którym ukazuje wierny obraz badanej rzeczywistości, unikając prezentyzmu historycznego. Dzięki temu lektura omawianej monografii staje się zrozumiała, ciekawa i wręcz pasjonująca, nawet dla przeciętnego czytelnika. Praca W. Cerana odznacza się dużymi walorami naukowymi; jest głęboko źródłowa, poprawna metodologicznie, krytyczna, wyważona i precyzyjna.

Na osobną uwagę zasługują liczne teksty obcojęzyczne, podane w korpusie pracy, które są świadectwem erudycji lingwistycznej Autora. $Z$ tej też racji omawiana pozycja, wydana po raz pierwszy w języku polskim przed 45 laty, nie traci nic ze swej aktualności. Należy podkreślić, że omawiana monografia jest dziełem oryginalnym i nowatorskim, nie tylko na gruncie polskim, ale i światowym oraz stanowi poważny wkład do badań nad myślą społeczną greckich pisarzy późnego antyku.

Jak wspomniano, praca W. Cerana w języku polskim ukazała się przed 45 laty - w roku 1969. Od tego czasu wydano wiele prac dotykających zagadnień omawianych przez W. Cerana oraz dokonano licznych tłumaczeń pism Jana Chryzostoma. $\mathrm{Z}$ tego względu przekładając omawianą monografię na język francuski należało uzupełnić ją o nowszą literaturę przedmiotu oraz istniejące przekłady francuskie dzieł Jana Chryzostoma. Tego niezwykle pracochłonnego zadania podjął się dr Paweł Filipczak. Jego zaangażowanie w perfekcyjne przygotowanie 
pracy W. Cerana niewatpliwie w znacznym stopniu przyczyniło się do jej uaktualnienia, a tym samym podniesienia jej walorów naukowych.

Cennym dopełnieniem omawianej pracy są dwa załączone artykuły, poprzedzone przedsłowiem [,Avant-Propos” (s. XI-XII), autorstwa P. Filipczaka], traktujące o życiu i działalności dydaktycznej oraz dorobku naukowym Profesora Waldemara Cerana [„Le professeur Waldemar Ceran” (s. XIII-XVII)], autorstwa prof. Sławomira Bralewskiego, a także informacje dotyczące współczesnych studiów polskich badaczy starożytności poświęconych późnoantycznej Antiochii [„Les études polonaises sur Antioche de l'antiquité tardive” (s. XIX-XXXIX)] autorstwa P. Filipczaka. Niezwykle wartościowe są też dodane indeksy: „Index des noms de personnes” (s. 222-226) i „Index des noms géographiques et ethniques" (s. 227-231) oraz wkładka ze zdjęciami Antiochii, jej okolic i odnalezionych mozaik (strony nienumerowane między s. 92 a 93), zawierająca 24 kolorowe zdjęcia, z czego 20 zdjęć jest autorstwa P. Filipczaka, a 4 są autorstwa D. Ossemana (pomimo iż każda z ilustracji jest podpisana, to jeszcze dodatkowo zamieszczono w pracy „Table des illustrations”, s. 219-221). Godne odnotowania jest też uzupełnienie bibliografii źródłowej („Sources”, s. 196-206) o nowe wydania i przekłady francuskie dzieł pisarzy starożytnych, a także ubogacenie bibliografii przedmiotowej („Études”, s. 207-218) o prace poświęcone Antiochii czasów Jana Chryzostoma opublikowane przez polskich uczonych.

Na zakończenie należy podkreślić, że ogłoszenie drukiem w serii Byzantina Lodziensia (tom XVIII) francuskiego przekładu monografii śp. Profesora Waldemara Cerana Artisans et commerçants à Antioche et leur rang social (seconde moitié du IVe siècle de notre ère) jest niezwykle cenną i pomysłową promocją nie tylko osiagnnięć zmarłego Profesora, lecz także współczesnej polskiej bizantynistyki. Pozostaje nam ufać, że inicjatywa łódzkich bizantynistów spotka się z pozytywnym odbiorem patrologów i historyków starożytności z kręgu języka francuskiego, a dzięki temu polskie studia nad późnoantyczną Antiochią staną się znane szerszemu gronu badaczy antyku.

ks. Piotr Szczur - Lublin, KUL

\section{Josef Andreas JUNGMANN SJ, Liturgia pierwotnego Kościoła do czasów Grzegorza Wielkiego, tlum. Teresa Lubowiecka, posłowie: ks. Helmut J. So- beczko, Modlitwa Kościoła 16, Kraków 2013, TYNIEC Wydawnictwo Bene- dyktynów, ss. 503.}

Ojciec J.A. Jungmann SJ (ur. 16 XI 1889 w Sand in Taufers - zm. 26 I 1975 w Innsbrucku) był jednym z pionierów odnowy liturgicznej oraz reformatorów soborowej i posoborowej liturgii w czasie zmian, które zaszły w Kościele Katolickim po Soborze Watykańskim II. Papież Jan XXIII (25 XI 1881 - 3 VI 1963, papież od 28 X 1958) w 1960 r. powołał go na eksperta soborowego jako członka komisji przygotowawczej, a następnie brał on udział m.in. w komisji soborowej 